\title{
DEFINING ICT IN A BOUNDARYLESS WORLD: THE DEVELOPMENT OF A WORKING HIERARCHY
}

\author{
Colrain M. Zuppo \\ Marion Technical College (MTC) \\ zuppoc@mtc.edu
}

\begin{abstract}
Subsequent to rapid information and communication technology development, the scope of the definition of Information and Communication Technologies (ICT or ICTs) has been utilized within diverse contexts including economic development, education, IT, business and personal usage. A review of academic literature, trade publications and general information was undertaken to establish a hierarchy of applications for the term ICT or ICTs.
\end{abstract}

\section{KEYWORDS}

ICT, ICTs, education, economics, digital communication, hierarchy

\section{INTRODUCTION}

The challenge of defining ICT, in a universal sense, becomes apparent when one considers that diverse applications of the term ICT exist within several contexts and treatments of the term. The continuum of definitions and applications of ICT one may encounter are further divided as the span of differences is represented in kinds rather than merely by degrees. Although the term ICT is found within a variety of contexts, there has been an underdeveloped response to the development of a framework for hierarchical classifications representing empirical definitions and applications of the term.

The acronym ICT (or ICTs) is used differently in education including benchmarks of digital literacy, economic sector definitions and regulations, information technology disciplines, socioeconomic development, and governance. The span of definitions within each type of application across the globe can vary widely however the primary definition of information and communication technologies revolves around the devices and infrastructures that facilitate the transfer of information through digital means.

Through the process of literature review, the researcher discovered the difficulty in finding consensus with regard to the definition of ICT. The outcome of that review highlighted the fact that there was a dearth of hierarchical structure in existence such that the researcher could easily identify the type of ICT relevant to their study within such a framework. As many researches have been conducted which focus upon ICT of all types, there was a fair amount of literature to draw from. This research is intended to attempt to answer that gap through a working hierarchy for classification of ICT which can be further developed as new developments in ICT occur. The hierarchy is intended to answer the need for an understanding of how the term is utilized across the globe. 
International Journal of Managing Information Technology (IJMIT) Vol.4, No.3, August 2012

\subsection{Statement of the Problem}

ICT is a common part of several bodies of knowledge which, in many cases, relies upon somewhat of a tacit definition of the term and the various applications in which it is utilized.

\subsection{Statement of the Purpose}

The purpose of this research was to develop a hierarchy for the definitions and applications of the term ICT (or ICTs). The focus of this research was to provide a broad perspective of ICT in order that a common hierarchy could be developed.

\subsection{Significance}

This research provides a contribution to the literature in a multi-disciplinary approach through development of a hierarchical framework that is relevant in a global sense. It was important to further explore the concept of defining and categorizing the applications ICTs due to the dearth of literature that has previously addressed the subject. Additionally, having a well-rounded view of ICTs not only informs future scholarly researches, but also will inform global operations in healthcare, disaster response, and business. The instant research also frames ICT from an economic and social perspective that the intended and unintended consequences of such technologies upon society as a whole.

Finally, providing a hierarchy for the term ICT will provide guidance for application of the span of definitions and applications of the term such that one may perform more precise keyword searches, resulting in more efficient and effective gathering of information relating to ICT.

\subsection{Definitions}

\subsubsection{ICT}

For purposes of this study, information and communication technologies (ICT) shall be interchangeably referred to as either ICT or ICTs, based upon the wide variation of usage of the term.

\subsubsection{Hierarchy}

For purposes of this study, a hierarchy or hierarchical classification refers to a framework for classification of ICT that includes definition of the term, identification of devices/architectures, nomenclature, and classification of definitions and applications.

\section{METHOD}

\subsection{Research Questions}

- What is ICT?

- What devices and/or infrastructures are considered ICT?

- How and in what settings are ICTs used?

- How do contexts of application of the term ICT differ between literatures and resources?

\subsection{Literature Review}

Internet searches were performed utilizing the keywords ICT and ICTs for an overview from books, websites, relevant blogs, and government resources. Scholarly publications were scanned utilizing the same keywords, searched with and without the additional keyword "definition". Business information repositories, including professional publications and magazines, were searched similarly. Information technology (IT) resources and databases (e.g. ITIL and Gartner) were also utilized. 
International Journal of Managing Information Technology (IJMIT) Vol.4, No.3, August 2012

\section{RESULTS}

\subsection{ICT and socioeconomic development}

In developed countries, technology represents wealth. Wireless technologies are ubiquitous in the United States and several other locations around the globe. However, in developing countries there is a disparity in coverage as it relates to mobile phone signals (e.g. sub-Saharan Africa) as obstacles to ICT development and utilization stem from economic development barriers. The International Telecommunication Union [1] stated that approximately 45 percent of Sub-Saharan African villages were covered by a mobile signal in 2006" (p. 2) despite the lack of universal access. The barriers to wide adoption of mobile and cellular phones include lack of electricity, lack of income to spend on ICTs, difficult terrain, and lack of transportation [1]. In contrast to the sub-Saharan African region is India, where access to cell phones is far greater than access to toilets [2].

The ITU is a specialized agency of the United Nations whose mission is to connect everyone in the world as a fundamental right to communicate. The ITU currently has a membership of over 192 countries and 700 private-sector entities and academic institutions [3]. The ITU coordinates the world's satellites which provide Internet connectivity, TV broadcasts, GPS navigation and weather information. The ITU also develops protocols, standards and agreements for global communication and facilitates support communication in the wake of disasters and emergencies.

The development of wireless connectivity, specifically in areas such as the sub-Saharan African region, is essential as ICTs have been shown to be useful in emergency or disaster situations. ICT development has also been presented as tools to assist villagers in accessing e-government services, for which development began in 2005-2006.

The World Health Organization (WHO) has utilized ICT for public health surveillance, which is the "continuous, systematic collection, analysis and interpretation of health-related data for planning, implementation, and evaluation of public health practice" [4]. During a disaster, such as an earthquake or tsunami, mobile phones with GPS capability can assist relief workers and emergency responders in gathering information and locating those who need assistance. In 2006, the WHO brought forth the proposal that ICT could potentially be useful in disaster response and recovery [5]. Yang, Yang, Lou and Gong [6] also suggested that cellular phones with GPS capabilities become a standard component of disaster preparedness plans in disaster-prone areas.

\subsection{ICT as an economic sector}

ICT has also been utilized as a definition of an economic sector. In 1998, the Organisation for Economic Co-operation and Development (OECD) agreed upon a definition based upon an international standard classification of activities rather than a classification of products. In 2002, the OECD reconvened discussions regarding the definition of ICT and clearly delineated manufacturing from services, removing some peripheral components of the previous definition which included office equipment and supplies [7]. The resulting definition of the economic sector included electronic displays, various types of cable, instruments for navigating and numerous other types of electronic and wireless connectivity-related devices.

Angeleski, Mitrevski, and Janeska [8] explain that e-readiness is "the capacity of a nation to participate in the digital economy or the ability of a nation to make connection with the rest of the world" (p. 266). The authors further explain that e-readiness provides a measure of ICT adoption levels as well as an indicator of "socio-economic functioning" (p. 266). Angeleski, et al, [8] argue that all countries should understand their ICT capabilities from the statistical standpoint for purposes of evaluation and improvement of their standing within the global digital economy.

Cohen, Garibaldi, and Scarpetta [9] point out that ICT can conceptually raise productivity growth in ICT-manufacturing sectors, increase the amount of capital being invested in ICT, and/or realize 
International Journal of Managing Information Technology (IJMIT) Vol.4, No.3, August 2012

efficiency gains by ICT adoption. Despite the decrease in the cost of ICT and the increase of availability, the authors point out that in many cases, the process of realizing the positive outcomes of ICT, investment in worker up skilling and training is required which results in a more protracted timeframe to realize those positive outcomes.

\subsection{ICTs and education}

ICTs are widely used in education in the United States and other countries. In 2007, the International ICT Literacy Panel produced a special report entitled "Digital transformation: A framework for ICT literacy". The Panel was sponsored by the Educational Testing Service (ETS) who defines ICT as a "continuum of skills and abilities" [10](p. 1). The report noted that "ICT is being used increasingly by global industry, international media, and academics to reflect the convergence between computer and communication technologies. Summarily, within the realm of education, ICT can be viewed as a set of activities and technologies that fall into the union of IT and telecommunications" (p. 2).

A number of education-related researches discuss the implementation and effectiveness of ICTs in the classroom, however, the term ICT or ICTs are utilized in a broad manner that could include PCs, desktops, laptops, handheld devices and other types of wireless or cable-connected equipment. The emphasis in educational research appears to be on competency development as can be seen in Jarnieson-Proctor, Watson, Finger, Grimbeek, and Burnett [11] and Clark, Demont-Heinrich, and Webber [12].

In their study of adult learning in the digital age, Selwyn, Gorard, and Furlong [13] lament the broad reference and usage of the term ICT. The authors state that "the umbrella term 'ICT' refers to a range of different, albeit rapidly converging technologies [and] there is a tendency...to use either too narrow a definition of ICT in terms of specific technologies or else too broad a definition....as a homogenous concept" (p. 20).

\subsection{ICTs and business}

Zhang, Aikman and Sun [14] define ICTs as "technologies used by people and organizations for their information processing and communication purposes" (p. 628). ITIL ${ }^{\circledR}$, "the most widely accepted approach to IT service management in the world" [15], defines ICT as:

"The application of science to the processing of data according to programmed instructions in order to derive results. In the widest sense, ICT includes all communications, information and related technology. The term Information Technology (IT) is used in a narrower sense, typically excluding telecommunications (voice) technology while including data networks (although almost all networks today are digital), as a reference to the systems that support information processing" [15].

Various professional resources such as CIO Magazine and TechTerms.com offer definitions that are equally as broad including:

"ICT refers to technologies that provide access to information through telecommunications. It is similar to Information Technology (IT), but focuses primarily on communication technologies. This includes the Internet, wireless networks, cell phones, and other communication mediums.

In the past few decades, information and communication technologies have provided society with a vast array of new communication capabilities. For example, people can communicate in real-time with others in different countries using technologies such as instant messaging, voice over IP (VoIP), and video-conferencing. Social networking websites like Facebook allow users from all over the world to remain in contact and communicate on a regular basis. 
International Journal of Managing Information Technology (IJMIT) Vol.4, No.3, August 2012

Modern information and communication technologies have created a "global village," in which people can communicate with others across the world as if they were living next door. For this reason, ICT is often studied in the context of how modern communication technologies affect society"[16].

\subsection{Professional Bodies of Knowledge and ICT}

In 2007, the European Commission for the Directorate, General Enterprise and Industry, published a report outlining recommendations based upon research led by the Innovation Value Institute at National University of Ireland Maynooth and the Council of European Professional Informatics Societies [17]. The EU adopted the e-Skills for the $21^{\text {st }}$ Century which were designed to set forth long term efforts to mature the ICT profession in Europe. The research was intended to set in motion a collaborative effort between scholars and industry practitioners to not only continue development on the framework of professional competencies and skills, but it was intended to facilitate the addressing of skills gaps under a sustainable operating model for the profession [17].

The Information Technology Certified Professional (ITCP) of New Zealand draws its body of knowledge and certification standards from the Skills Framework for the Information Age (SFIA) in the United Kingdom. The ITCP includes 86 specific skills broken into seven areas of competency with three assessment domains. The stated goal of the certification is to assist in the maturation of ICT as a profession and recognizes international growth of IT domains as well as the need for standardization of knowledge, skills, and abilities [18]. ITCP's efforts to advance ICT as a profession are part of global programs coordinated by the IP3 Taskforce which is under the umbrella of the International Federation for Information Processing (IFIP).

The Australian Computer Society (ACS) sets forth The ICT Profession Body of Knowledge as sanctioned by their Professional Standards Board. The ACS provides a stakeholder list that defines the breadth of the ICT profession as including "academic disciplinary bodies, educationalists, government, industry, professional standards bodies, students, and community" [19]. Similar to the ITCP, the certifications offered by the ACS are coordinated with the IFIP through the IP3's SFIA.

\section{RESULTS}

From the organizational perspective, the workplace has evolved from a discrete time-bound and defined place to a timeless, wall-less and sometimes virtual existence. From the economic development perspective, technology facilitates a reduction in the digital divide where ICT assists disaster preparedness, response, and communication. In education, ICTs are a vehicle for teaching and learning through active application. Moreover, those developing countries that do not have ICT access are considered to be among the "digital poor" [20] (p. 32). An additional dynamic of ICT classification is that the term is used to describe an economic sector that produces and services devices and components within the classification of ICT.

The hierarchy represented below provides for distinctions between the classifications and applications of ICT within a cross-disciplinary framework.

\subsection{Hierarchy}

Figure 1 represents the hierarchy developed from the review of literature. 
International Journal of Managing Information Technology (IJMIT) Vol.4, No.3, August 2012

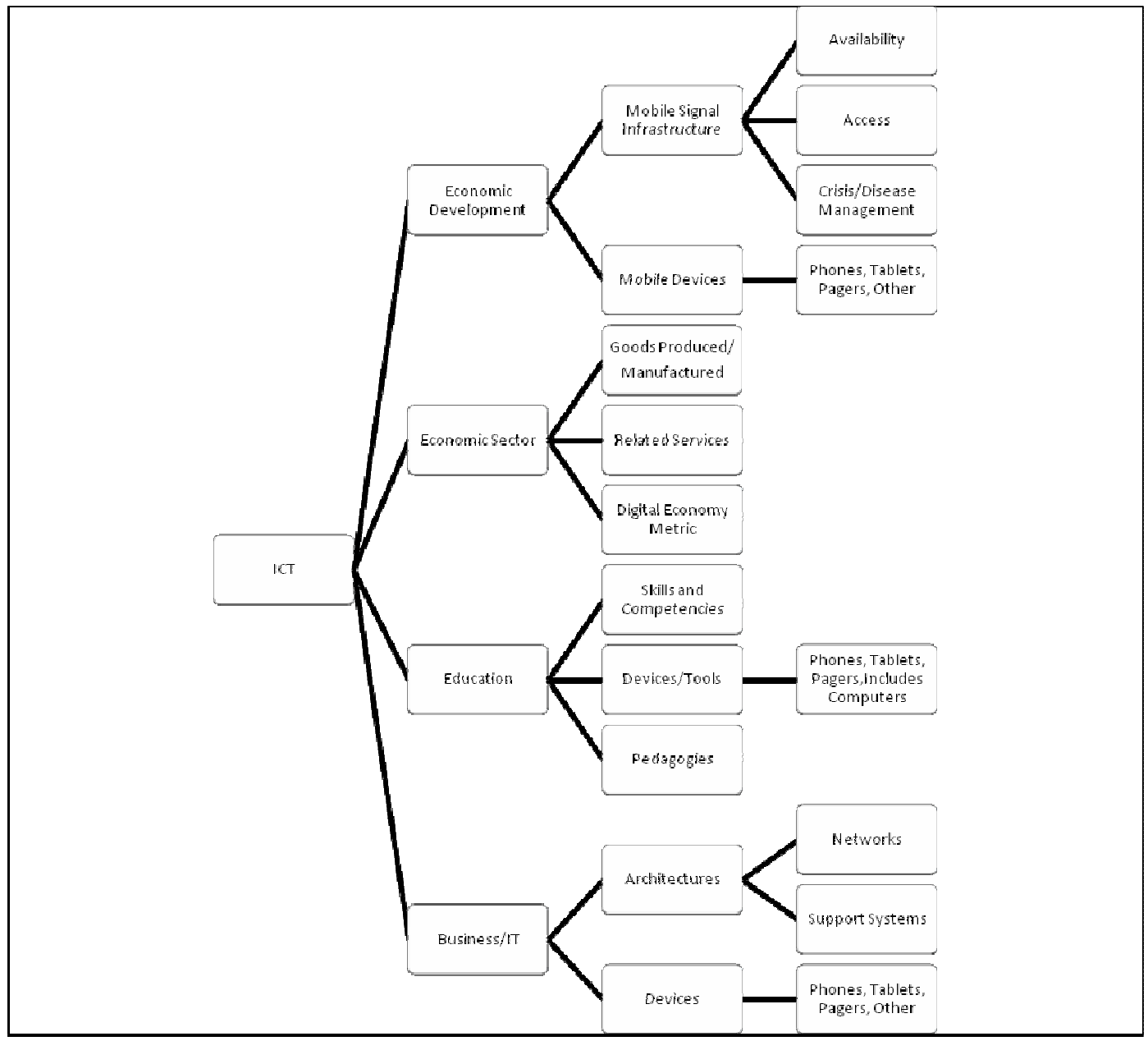

Figure 1. ICT Hierarchy

Four classifications of applications and definitions of ICT are represented:

1. ICT

1.1 Economic Development

1.1.1. Mobile Signal/Towers/Satellites

1.1.1.1. Access

1.1.1.2. Availability

1.1.1.3. Crisis Management/Disease Management

1.1.2. Mobile Devices

1.1.2.1. Phones, pagers, tablets, other wireless devices

1.2 Economic Sector

1.2.1. Goods Produced/Manufactured

1.2.2. Related Services

1.2.3. Digital Economy Readiness Metric

\subsection{Education}

1.3.1. Skills and Competencies

1.3.2. Devices/Tools

1.3.2.1. Phones, pagers, tablets, other wireless devices including computers 
International Journal of Managing Information Technology (IJMIT) Vol.4, No.3, August 2012

\author{
1.4 Business/IT \\ 1.3.3. Pedagogies \\ 1.4.1. Architectures \\ 1.4.1.1. Networks \\ 1.4.1.2. Support Systems
}

1.4.2. Phones, pagers, tablets, other wireless devices

\title{
4.2. Discussion
}

While there may be some commonality in the way ICT was defined or applied within each decomposed level of the hierarchy, there remain distinct differences in the devices or contexts of each application of the term. For example, referring to ICTs within the context of education encompasses not only a reference to equipment (i.e. devices) but also to a group of skills or competencies that teachers and students must possess in order to be considered having achieved a certain level of competencies as it relates to ICTs.

Economic (or regional) development efforts relating to ICT overlap with ICT as an economic sector; however the measurement of metrics such as digital readiness of a country is somewhat dependent upon the strength of related economic sectors as well as the ability of that country to successfully move beyond the barriers of rough terrain, lack of electricity, lack of funding, and low likelihood of adoption. When one refers to ICT as an economic sector, the reference is in regard to goods manufactured or produced (e.g. cell phones, wireless modems and access points, etc.) or related services (e.g. repair, installation). In the economic development sense, support from the economic sector of ICT is necessary and could not exist without the other, regardless of indigenous availability for purchase.

Similarly, the definitions and application of ICTs within a business/IT context rely upon an established economic sector in addition to a well-fortified regional, national and international ICT infrastructure. Divergently, the term ICTs refers to devices and networks/systems related to the support those devices which have become tools of inter/intra organizational communication to facilitate conducting business in a globalized economy.

All levels of decomposition throughout the ICT hierarchy contain some degree of commonality in that they are related to technologies that facilitate the transfer of information and various types of electronically mediated communication. Not all levels of the ICT hierarchy involve voice communications and only some levels of the hierarchy refer to methodologies associated with ICTs (e.g. educational pedagogies or methodologies for teaching). Additionally, education seems to encompass sets of competencies or skills as benchmarks for proficiencies. Certainly ICT architecture and administration necessitate competencies and proficiencies, however, those competencies are inherent to the work of the ICT/IT application. Business does not assess ICT capabilities in order for one to send a text message to a co-worker in another time zone, across the globe (though perhaps they should consider such things).

\subsection{Limitations}

This study was limited in that despite an exhaustive search of various types of literature and reference materials, every dynamic and application of the term ICT (or ICTs) would have been impossible to discover and include. Therefore, the researcher utilized a hierarchical classification system based upon the most common definitions and applications of the term. The hierarchy included economic development, economic sector(s), education tools, methods, and skills, and business/IT applications. Based upon those results, a framework for a hierarchy was constructed as a means for a starting point for a larger classification system relating to ICT. 
International Journal of Managing Information Technology (IJMIT) Vol.4, No.3, August 2012

\subsection{Directions for Future Research}

Future research could provide additional levels of decomposition of the ICT hierarchy that would include a more detailed view of goods, services, applications, methodologies, infrastructures, and competencies. The instant research serves as a beginning point for such endeavours and is designed to inform the research of scholars and practitioners, as well as government officials, health workers, and educators. Efforts to decompose the ICT hierarchy further could perhaps be utilized to develop a full ICT taxonomy that may supply a universal view of the definitions and applications of the term beyond the scope of this study.

\section{CONCLUSiON}

ICT (or ICTs) have become synonymous with productivity and enabled communication within a global context. As evidenced by the persistence of the digital divide between those who have access to ICT and those who do not, it is important to understand the span of the effects of ICT where ICTs are ubiquitous as much as where they are not due to economic development barriers. Further, gleaning an understanding of ICT as a profession can inform socioeconomic development and sustainable operating models for training and development.

To study ICT in any context, one must have at least a working definition within the context of the application of interest. In order to define ICT (or ICTs), one must understand the scope of appropriate definitions as well as the relevant applications of the term. Once an understanding of the range of possibilities has been achieved, a more targeted search can be preformed and the noise of unrelated or unproductive results can be set aside.

Based upon current trends in ICT, a broader understanding of the comprehensive term ICT is timely and important such that diffusion of ICT can be broadened and adoption can assist society in ways not previously imagined. One only has to think of the benefits of ICT during a disaster such as the 2004 Phuket (Thailand) tsunami [21] or the 2011 Fukushima (Japan) earthquake [22] to understand the power of communication during catastrophic events.

\section{ACKNOWLEDGEMENTS}

The author would like to thank Dr. Donna K. Trautman of Bowling Green State University for expert guidance during the dissertation process that subsequently led to the publication of the instant research. The author would also like to thank Esum Hcraeser for clarity and expansion of this and related topics.

\section{REFERENCES}

[1] International Telecommunication Union. (2007). Measuring village ICT in sub-Saharan Africa. Retrieved from http://www.itu.int/ITU-D/ict/statistics/material/Africa_Village_ICT_2007.pdf.

[2] United Nations University. (2010). Greater Access to Cell Phones than Toilets in India. Retrieved from http://www.inweh.unu.edu/News/2010-04_UNU-INWEH_News-Release_Sanitation.pdf.

[3] International Telecommunication Union. (n.d.). Who we are. Retrieved from http://www.itu.int/en/about/Pages/default.aspx.

[4] World Health Organization. (2011). 2011-last update: Information and communication technologies for public health emergency management. Retrieved from http://www.who.int/csr/ict4phem/en/index.html 
International Journal of Managing Information Technology (IJMIT) Vol.4, No.3, August 2012

[5] World Health Organization. (2006). Health aspects of disaster preparedness and response: Report from a regional meeting of countries of South East Asia, Bangkok, Thailand, 21-23 November 2005. Prehospital \& Disaster Medicine, 21(5), 62-78.

[6] Yang, C., Yang, J., Luo, X., and Gong, P. (2009). Use of mobile phones in an emergency reporting system for infectious disease surveillance after the Sichuan earthquake in China. Bulletin of the World Health Organization, 87(8), 619-623.

[7] Organisation for Co-operation and Development (OECD). (2002). Retrieved from http://www.oecd.org/dataoecd/63/60/1933354.pdf.

[8] Angeleski, M., Mitrevski, P., and Janeska, M. (2009). "Composite index of e-business strategy readiness of the enterprises in the Republic of Macedonia" in ICT Innovations 2009, Davcev, D., and Marx Gomex, J., (Eds.), p. 265-275. Springer-Verlag Berlin Heidelberg, Scientific Publishing Services Pvt. Ltd.

[9] Cohen, D., Garibaldi, P., and Scarpetta, S., (Eds.). (2004). The ICT Revolution: Productivity, Differences and the Digital Divide. Oxford University Press, University of Oxford.

[10] Educational Testing Service. (2007). Digital transformation: A framework for ICT literacy. A report of the International ICT Literacy Panel. Retrieved from http://www.ets.org/Media/Tests/Information_and_Communication_Technology_Literacy/ictreport.pd f.

[11] Jarnieson-Proctor, R., Watson, G., Finger, G., Grimbeek, P., \& Burnett, P. C. (2007). Measuring the use of Information and Communication Technologies (ICTs) in the classroom. Computers in the Schools, 24(1/2), 167-184. doi:10.1300/J025v24n0111.

[12] Clark, L., Demont-Heinrich, C., \& Webber, S. (2005). Parents, ICTs, and children's prospects for success: Interviews along the digital “Access Rainbow”. Critical Studies in Media Communication, 22(5), 409-426. doi:10.1080/07393180500342985.

[13] Selwin, N., Gorard, S., \& Furlong, J. (2006). Adult learning in the digital age: Information technology and the learning society. Routledge, Taylor \& Francis Group.

[14] Zhang, P., Aikman, S., \& Sun, H. (2008). Two types of attitudes in ICT acceptance and use. International Journal of Human Interaction, 24(7), 628-648. doi: 10.1080/10447310802335482.

[15] Information Technology Infrastructure Library [ITIL]. (n.d.). ITIL glossaries. Retrieved from http://www.itil-officialsite.com/InternationalActivities/ITILGlossaries_2.aspx.

[16] TechTerms.com. (n.d.). Definition of ICT. Retrieved from http://www.techterms.com/definition/ict.

[17] Innovation Value Institute at National University of Ireland Maynooth. (n.d.). IVI and CEPIS develop European Framework for ICT Professionalism. Retrieved from http://ivi.nuim.ie/news-events/ivi-andcepis-develop-european-framework-ict-professionalism

[18] Institute of IT Professionals, New Zealand. (n.d.). ITCP - IT Certified Professional. Retrieved from http://www.itcp.org.nz/about

[19] Professional Standards Board, Australian Computer Society. (2012.). The ICT professional body of knowledge. Retrieved from http://www.acs.org.au/_data/assets/pdf_file/0007/7792/The-ICTProfession-Body-of-Knowledge-July-2012.pdf

[20] Galperin, H., and Mariscal, J. (2007). Digital Poverty: Latin American and Caribbean Perspectives. International Development Research Centre, Intermediate Technology Publications Ltd.

[21] National Geographic News. (2005). The deadliest tsumani in history? Retrieved from http://news.nationalgeographic.com/news/2004/12/1227_041226_tsunami.html. 
International Journal of Managing Information Technology (IJMIT) Vol.4, No.3, August 2012

[22] The Telegraph. (2011). Japan earthquake, tsunami and Fukushima nuclear disaster: 2011 review. Retrieved from http://www.telegraph.co.uk/news/worldnews/asia/japan/8953574/Japan-earthquaketsunami-and-Fukushima-nuclear-disaster-2011-review.html.

\section{Author}

Colrain M. Zuppo earned a PhD in Technology Management from Indiana State University with a specialization in Human Resource Development and Industrial Training. Cori's dissertation research was entitled "Organizations as consumers of human capital via technology: A policy study of information and communication technologies". Cori also holds an M.A.Ed. from The George Washington University and a B.S. in Conflict Resolution from Ohio University. Cori is a Professor in the Department of Business and Information

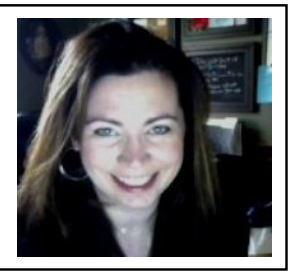
Technology at Marion Technical College (MTC) and served as part time faculty and doctoral fellow at Bowling Green State University, conducting research and teaching in the areas of technology management, academic research and instructional design \& delivery. 